\title{
Akad Shulh dalam Sengketa Hukum Muamalah (Litigasi dan Non Litigasi)
}

\author{
Ma'rifah Yuliani \\ Sekolah Tinggi Ilmu Ekonomi Muhammadiyah Tanjung Redeb \\ Email: marifahyuliani@gmail.com
}

\begin{abstract}
Akad Shulh in Muamalah Dispute (Litigation and Non Litigation). This study aims to determine the use of shulh contract in sharia law law disputes (muamalah) either in court (litigation) or outside court (non litigation). The results of this study indicate that the contract of shulh outside the court process (non litigation) is seen from the use of negotiation, mediation, arbitration aimed at reconciling the two disputing parties. The use of shulh contract in litigation is known by the process of mediation in court, which initially only in the form of recommendation from the provisions of Article 154 R.Bg/130 HIR. However after PERMA no. 01 of 2008, the mediation process of peaceful dispute resolution becomes coercive. Shulh which is a peace is included in Book II on Akad in the Compilation of Islamic Economic Law.
\end{abstract}

Keywords: Shulh, Dispute Settlement, Litigation.

\begin{abstract}
Abstrak: Akad Shulh dalam Sengketa Muamalah (Litigasi dan Non Litigasi). Penelitian ini bertujuan untuk mengetahui penggunaan akad shulh dalam sengketa hukum ekonomi syariah (muamalab) baik di dalam pengadilan (litigasi) maupun di luar pengadilan (non litigasi). Hasil penelitian ini menyebutkan bahwa penggunaan akad shulh di luar proses pengadilan (non litigasi) terlihat dari penggunaan negosiasi, mediasi, arbitrase yang bertujuan untuk mendamaikan kedua belah pihak yang berselisih. Adapun penggunaan akad shulh pada litigasi diketahui dengan proses adanya mediasi di pengadilan, yang awalnya hanya berupa anjuran dari ketentuan Pasal 154 R.Bg/130
\end{abstract}


HIR. Namun setelah lahirnya PERMA No. 01 Tahun 2008 maka proses mediasi atas penyelesaian sengketa secara damai menjadi bersifat memaksa. Shulh yang merupakan perdamaian dimasukkan ke dalam Buku II tentang Akad dalam Kompilasi Hukum Ekonomi Syariah.

\section{Kata Kunci: Shulh, Penyelesaian Sengketa, Litigasi.}

\section{Pendahuluan}

Interaksi antar sesama adalah sebagai salah satu ciri manusia sebagai makhluk sosial. Interaksi itu terjadi baik sesama individu maupun kelompok lain disekitarnya. Interaksi yang dilakukan memang dimaksudkan selain untuk memenuhi kebutuhan hidup masingmasing, juga untuk memenuhi hajat sosial orang banyak. Banyak kegiatan yang dilakukan manusia dalam memenuhi hajat hidupnya, termasuk didalamnya kegiatan ekonomi.

Untuk kegiatan ekonomi masyarakat Indonesia yang berkembang pesat belakangan ini, menuntut keterlibatan berbagai pihak baik langsung maupun tidak langsung dan tidak menutup kemungkinan terjadi adanya kesalahfahaman antara satu pihak dengan pihak lainnya, atau antara satu pelaku atau kelompok pelaku bisnis dengan kelompok pelaku bisnis lainnya. Kesalahfahaman dimaksud ada yang dapat diselesaikan saat itu juga tapi terkadang ada pula yang berujung pada konflik atau sengketa di antara mereka.

Ada banyak terdapat jenis sengketa dalam kehidupan masyarakat yang mana setiap jenis sengketa, apapun yang terjadi selalu menuntut pemecahan dan penyelesaian. Demikian juga dengan sengketa ekonomi, semakin luas dan banyak frekuensi kegiatan ekonomi di masyarakat berpeluang semakin banyaknya kemungkinan sengketa yang muncul. Hal ini menunjukkan semakin banyaknya dibutuhkan sistem penyelesaian untuk sengketa-sengketa tersebut. Karena apapun jenis sengketa yang muncul menuntut penyelesaian yang bijaksana yang tidak merugikan kedua belah pihak. 
Jurnal Syariah: Jurnal Ilmu Hukum dan Pemikiran Vol 17, Nomor 2 Desember 2017

Demikian pula dengan sengketa dalam bidang ekonomi juga menuntut penyelesaian yang tepat dan cepat. Bila hal tersebut tidak dilakukan, maka kemungkinan akan berakibat penurunan produktifitas ekonomi atau bahkan dalam skala besar akan mengakibatkan kerugian di kalangan konsumen. ${ }^{1}$

Sengketa atau konflik merupakan problema sosial yang langsung bersentuhan dengan hukum dan memerlukan pemecahan secara integral. Setiap tatanan masyarakat memiliki berbagai macam cara untuk memperoleh kesepakatan dalam proses perkara atau untuk menyelesaikan sengketa atau konflik di lingkungan mereka. Kebutuhan penyelesaian sengketa di antara masyarakat berbeda satu sama lain. Ada berbagai macam cara penyelesaian sengketa yang ada di masyarakat yang masing-masing memiliki keunggulan dan kelemahan tertentu. Penyelesaian mengandung makna baik sebagai lembaga, proses maupun produk.

1 Yusna Zaidah, Penyelesaian Sengketa Melalui Peradilan dan Arbitrase Syariah di Indonesia, (Yogyakarta: Aswaja Pressindo, 2015), h. 1-2.
Akad Shulh dalam Sengketa ..127-142 Ma'rifah Yuliani

Secara garis besar ada beberapa cara penyelesaian sengketa, yakni:

1. Litigasi, yakni melalui pengadilan. Berdasarkan pasal 24 UUD 1945 jo Pasal 2 UU No. 4 tahun 2004 tentang Kekuasaan Kehakiman disebutkan bahwa penyelenggaraan kehakiman di Indonesia diselenggarakan oleh sebuah Mahkamah Agung dan sebuah Mahkamah Konstitusi. Dibawah Mahkamah Agung ada beberapa lingkungan peradilan yang ada di Indonesia, yaitu: Peradilan Umum, Peradilan Agama, Peradilan Tata Usaha Negara, dan Peradilan Militer.

$$
\begin{aligned}
& \text { 2. Non Litigasi (Di } r \text { Luar } \\
& \text { Pengadilan)/Alternative } \\
& \text { Resolution (ADR). } \\
& \text { Khusus penyelesaian }
\end{aligned}
$$
melalui lembaga sosial di luar pengadilan umum disebut Alternative Dispute Resolution (ADR). Menurut Basuki Rekso Wibowo, cara ini berbasiskan pada kesepakatan dan kesukarelaan para pihak yang bersengketa. Penyelesaian sengketa model ini adalah penyelesaian sengketa di luar pengadilan yang didasarkan kepada hukum, dan penyelesaian 
Jurnal Syariah: Jurnal Ilmu Hukum dan Pemikiran Vol 17, Nomor 2 Desember 2017
Akad Shulh dalam Sengketa ..127-142

Ma'rifah Yuliani tersebut dapat digolongkan kepada penyelesaian yang berkualitas tinggi.

Pranata alternatif penyelesaian sengketa yang dikenalkan oleh UU No. 30 tahun 1999, sebagaimana diatur dalam Pasal 6 terdiri dari:

a. Penyelesaian yang dapat dilaksanakan sendiri oleh para pihak dan bentuk negosiasi.

b. Penyelesaian sengketa yang diselenggarakan melalui (dengan bantuan) pihak ketiga yang netral di luar para pihak yaitu dalam bentuk mediasi.

Kemudian jika cara diatas menemui jalan buntu maka penyelesaian diserahkan ke arbitrase. Dengan demikian, secara umum cara penyelesaian sengketa di luar pengadilan (ADR) dikenal dalam bentuk berbagai penyelesaian.

Bentuk-bentuk penyelesaian tersebut yakni: Negosiasi; Konsultasi; Mediasi; Konsiliasi; dan Arbitrase. ${ }^{2}$

\section{Begitu} kompleksnya permasalahan mengenai penyelesaian

\footnotetext{
${ }^{2}$ Ibid, h. 5-33.
}

sengketa yang terjadi, terlebih diranah ekonomi (muamalah), yang khususnya di lingkungan ekonomi yang berbasiskan syariah Islam maka memunculkan pertanyaan adakah dikenal penyelesaian sengketa di dalam Islam, terlebih di ranah muamalah.

Sengketa muamalah adalah sengketa yang terjadi antara dua pihak atau lebih yang mana objek sengketa adalah transaksi kehartabendaan (mu'awadaah al-maliyah). Mahmud Hilmy memandang sengketa muamalah dengan sengketa yang terjadi dalam lingkup pemindahan harta dan hak, dari satu pihak kepada pihak lain melalui proses akad. Mediasi dalam muamalah tertumpu pembahasannya pada akad perdamaian yang mengakhiri sengketa kehartabendaan.

Dalam hukum Islam, upaya perdamaian yang dilakukan oleh para pihak untuk menyelesaikan sengketa muamalah dikenal dengan shulh. Shulh sebagai sarana perwujudan perdamain dapat diupayakan oleh pihak yang bersengketa atau dari pihak ketiga yang berusaha membantu para pihak 
menyelesaikan sengketa mereka. $^{3}$ dilakukan di luar persidangan, maupun Bahkan di dalam Kompilasi Hukum sebelum pengadilan terjadi.

Ekonomi Syariah (KHES), Shulh

dimasukkan ke dalam bagian Buku II yang berisikan pembahasan mengenai akad.

Dari penjelasan latar belakang di atas, yang akan menjadi rumusan masalah pada penelitian ini adalah bagaimanakah akad shulh dalam sengketa muamalah (litigasi dan non litigasi). Adapun tujuan penulisan penelitian ini adalah penggunaan akad shulb dalam sengketa muamalah (litigasi dan non litigasi). Adapun manfaat dari penulisan penelitian ini adalah untuk menambah wawasan mengenai sengketa dalam ranah ekonomi syariah, dalam hal ini adanya penyelesaian sengketa secara damai dengan penggunaan akad shulh dalam sengketa muamalah (litigasi dan non litigasi), dan manfaat lainnya dari tulisan ini adalah informasi bahwa perdamaian dari sebuah konflik atau sengketa antara dua belah pihak bisa

\footnotetext{
3 Syahrizal Abbas, Mediasi dalam Hukum Syariah, Hukum Adat dan Hukum Nasional, (Jakarta: Kencana, 2011) h. 203-204.
}

\section{Pembahasan}

A. Pengertian Shulh

Dalam Ensiklopedi Hukum Islam, Secara bahasa as-sulb adalah akad untuk menyelesaikan suatu pertengkaran atau perselisihan menjadi perdamaian. ${ }^{4} \quad$ Yakni perjanjian untuk saling menghilangkan permusuhan, perbantahan, pendendaman dan sikap-sikap yang dapat menimbulkan permusuhan maupun peperangan. ${ }^{5}$

Sayyid Sabiq memberikan pengertian shulh dengan akad yang mengakhiri persengketaan antara dua pihak. ${ }^{6}$ Dengan demikian, akad yang digunakan dalam shulh bertujuan untuk mengakhiri atau menyelesaikan pertengkaran antara

4 Abdul Azis Dahlan, ed, Ensiklopedi Hukum Islam, (Jakarta: Ichtiar Baru van Hoeve, 1996), h. 1653.

${ }_{5}^{5}$ M. Abdul Mujieb, dkk, Kamus Istilah Fiqih, (Jakarta: Pustaka Firdaus, 1995), h. 328.

6 Sayyid Sabiq, Fikih Sunnab: juz 13, diterjemahkan oleh Kamaluddin A. Marzuki, (Bandung: Al-Ma'arif, 1997), h. 189. 
Jurnal Syariah: Jurnal Ilmu Hukum dan Pemikiran

dua pihak yang terikat dengan akad sebelumnya. Akad yang digunakan dalam shulh bertujuan untuk mewujudkan perdamaian antara para pihak yang terlibat dalam persengketaan. ${ }^{7}$

Pengertian Shulb juga merupakan suatu jenis akad untuk mengakhiri jenis perselisihan atau kesepakatan untuk menyelesaikan pertikaian secara damai dan saling memaafkan. ${ }^{8}$

\section{B. Dasar Hukum Shulh}

Dasar hukum shulh dalam Alquran terdapat dalam Q.S. AnNisa'/4:128 yang artinya:

"Dan jika seorang perempuan khawatir suaminya akan nusyuz atau bersikap tidak acuh, maka keduanya mengadakan perdamaian yang sebenarnya dan perdamaian itu lebih baik (bagi mereka) walaupun

7 Wahbah Az-Zuhaily, Fiqib Islami Wa Adillatubu 6, diterjemahkan oleh Abdul Hayyie al-Kattani, dkk, (Jakarta: Gema Insani, 2011), h. 235.

8 Ahmad Mujahiddin, Kewenangan dan Prosedur Penyelesaian Sengketa Ekonomi Syariah di Indonesia, (Bogor: Ghalia Indonesia, 2010), h. 280.
Akad Shulh dalam Sengketa ..127-142

Ma'rifah Yuliani manusia itu menurut tabiatnya kikir.

Dan jika kamu memperbaiki (pergaulan dengan isterimu) dan memelihara dirimu (dari nusyuz dan sikap acuh tak acuh). Maka Sesungguhnya Allah adalah Maha mengetahui apa yang kamu kerjakan. (QS. An-Nisa'/4 : 128)

Dasar hukum berikutnya Q.S. Al-Hujurat/49:9 yang artinya: "Dan apabila ada dua golongan orang mukmin berperang, maka damaikanlah antara keduanya. Jika salah satu dari keduanya berbuat zalim terhadap (golongan) yang lain, maka perangilah (golongan) yang berbuat zalim itu, sehingga golongan itu kembali pada perintah Allah. Jika golongan itu telah kembali (kepada perintah Allah), maka damaikanlah antara keduanya dengan adil, dan berlakulah adil. Sesungguhnya Allah mencintai orang-orang yang berlaku adil.” (QS. Al-Hujurat: 9).

Berdasarkan kedua ayat Alquran di atas, Wahbah Az-Zuhaily dan Sayyid Sabiq menyatakan bahwa hukum dasar penggunaan shulh 
dalam menyelesaikan sengketa adalah boleh (an-nadb). Kedua tokoh ini cenderung sepakat bahwa penggunaan shulh dilakukan di luar pengadilan, di mana para pihak bersepakat untuk tidak menempuh jalur hukum dalam menyelesaikan sengketa mereka. ${ }^{9}$

\section{Rukun Shulh}

Para ulama cenderung merumuskan rukun shulh dalam dua pandangan berbeda. Jumhur lama berpandangan bahwa rukun-rukun shulh adalah sebagai berikut:

1. Adanya dua orang yang melakukan akad;

2. Ada ijab dan kabul;

3. Adanya persoalan yang mereka perselisihkan; dan

4. Terdapat bentuk perdamaian yang mereka sepakati.

Sedangkan mazhab Hanafi menyebutkan bahwa shulh itu hanyalah ijab dan Kabul. Selain ijab dan Kabul, ulama Hanafi tidak mengategorikan ke dalam rukun

\footnotetext{
${ }^{9}$ Syahrizal Abbas, Op. Cit., h. 206
}

shulh, tetapi memasukkan ke dalam syarat shulh. ${ }^{10}$

D. Berakhirnya Akad Shulh

Akad shulh akan berakhir apabila:

1. Pencabutan perjanjian damai kecuali dalam persoalan qishas;

2. Larinya orang murtad yang ikut sebagai pihak dalam perjanjian tersebut ke negeri harb atau mati dalam pemberontakan. Hal ini merupakan persyaratan menurut pendapat kelompok $\mathrm{Abu}$ Hanifah;

3. Didasarkan pada khiyar kecatatan atau berdasarkan penglihatan akan bentuk perdamaian sebab hal itu bertentangan dengan akad; dan

4. Kecelakaan pada salah satu pihak yang berdamai sebelum perdamaian ditetapkan. ${ }^{11}$

\section{E. Ketentuan Umum Shulh}

${ }^{10} \mathrm{Ibid,} \mathrm{h.} \mathrm{207-208.}$

11 Ahmad Mujahiddin, Op. Cit, h. 281. 
Jurnal Syariah: Jurnal Ilmu Hukum dan Pemikiran

Adapun ketentuan umum shulh yang terdapat dalam Kompilasi Hukum Ekonomi Syariah yang terdapat dalam pasal 521-524 adalah sebagai berikut:

1. Orang yang membuat suatu akad perdamaian harus cakap melakukan perbuatan hukum.

2. Suatu akad perdamaian yang dibuat oleh anak yang telah diberi izin oleh walinya adalah sah, selama perdamaian itu tidak berakibat kerugian yang nyata.

3. Jika seseorang mengajukan gugatan yang ditujukan kepada seorang anak yang telah diberi izin, dan anak itu membuat pengakuan atas hal itu, maka hasilnya adalah suatu bentuk akad perdamaian yang sah melalui pengakuan.

4. Seorang anak yang telah diberi izin, berhak untuk membuat suatu akad perdamaian yang sah dengan catatan ia diberi waktu untuk memikirkan tuntutannya.

5. Jika seorang anak menyetujui suatu akad perdamaian tentang
Akad Shulh dalam Sengketa ..127-142 Ma'rifah Yuliani

sebagian dari tuntutannya dan di samping itu ia juga memiliki bukti untuk menunjang tuntutannya tersebut, maka akad perdamaian itu tidak sah. Tetapi, jika ia tidak memiliki bukti semacam itu, serta lawannya bersedia untuk diangkat sumpah, maka akad perdamaian itu sah.

6. Jika seorang anak melakukan gugatan untuk mendapatkan kembali barang dari orang lain, dan kemudian membuat akad perdamaian tentang nilai tuntutannya, maka akad perdamaian itu adalah sah.

7. Wali seorang anak dibolehkan melakukan akad perdamaian atas gugatan terhadap harta anak, dengan ketentuan perdamaian tersebut tidak mengakibatkan kerugian yang nyata bagi anak itu.

8. Perdamaian dapat dilakukan sendiri oleh pihak yang berperkara atau orang yang dikuasakan untuk itu sepanjang disebutkan dalam surat kuasa. 
Jurnal Syariah: Jurnal Ilmu Hukum dan Pemikiran Vol 17, Nomor 2 Desember 2017

9. Pemberi kuasa tidak dibenarkan menyelesaikan sendiri perkaranya tanpa diketahui oleh penerima kuasa.

10. Jika seseorang menunjuk orang lain sebagai penerima kuasanya untuk melakukan perdamaian atas suatu gugatan, maka pemberi kuasa terikat dengan perdamaian itu.

11. Jika seorang penerima kuasa membuat suatu perdamaian dengan cara pengakuan bahwa ia akan mengganti harta dengan harta lain, lalu ia membuat perdamaian atas namanya sendiri, maka penerima kuasa semacam ini menjadi bertanggungjawab atas suatu tuntutan yang diajukan bertalian dengan hal tersebut, dan sejumlah uang yang diselesaikan dengan cara itu, bisa diperoleh kembali dari penerima kuasa tersebut, dan penerima
Akad Shulh dalam Sengketa ..127-142 Ma'rifah Yuliani

kuasanya sendiri bisa menuntut terhadap pemberi kuasanya. ${ }^{12}$

F. Penggantian Objek Shulh

Penggantian objek shulb akan terjadi apabila:

1. Jika penggantian objek perdamaian berupa barang tertentu, maka barang itu dianggap sebagai suatu barang sah sebagaimana barang asal;

2. Jika penggantian objek perdamaian itu berupa piutang, maka penggantian objek perdamaian dianggap sebagai pembayaran harga;

3. Penggantian objek perdamaian dari suatu perdamaian harus berupa harta milik dari orang yang membuat perdamaian; dan

4. Jika penggantian objek perdamaian berupa barang yang membutuhkan transaksi barang, maka penggantian objek
12 Dewan Syariah Nasional - Majelis Ulama Indonesia, Kompilasi Hukum Ekonomi Syariah, (Jakarta: Kencana, 2009), h, 142-144. 
perdamaian harus dinyatakan dengan jelas. ${ }^{13}$

G. Gugatan dalam Shulh

Adapun gugatan dalam shulh yang terdapat dalam Kompilasi Hukum Ekonomi Syariah yang terdapat dalam pasal 528-539 adalah sebagai berikut:

1. Jika akad perdamaian dibuat dengan materi yang berupa pengakuan atas harta yang disengketakan, maka perdamaian itu diakui sebagai sebab kepemilikan.

2. Jika seluruh atau sebagian dari pengganti objek perdamaian diambil dari seseorang yang berhak atas penggantian itu, maka penggantian objek perdamaian berupa barang yang digugat dari perdamaian itu, yakni bisa seluruhnya atau sebagiannya dinyatakan sah.

3. Jika akad perdamaian dibuat dengan pengakuan tentang manfaat suatu harta, maka

13 Ahmad Mujahidin, Op. Cit., h. 283. hukum akad perdamaian itu adalah sama dengan hukum akad ijarah.

4. Suatu perdamaian dengan cara penolakan atau bersikap diam saja, maka penggugat berhak atas harta penggantiannya, sedangkan tergugat berhak untuk tidak melakukan sumpah dan selesainya sengketa.

5. Hak syuf'ah (hak untuk didahulukan/preverence) yang melekat pada suatu benda tidak bergerak berlaku sebagai pengganti objek perdamaian.

6. Jika seseorang yang berhak atas harta itu lalu mengambil sebagian atau seluruh benda tidak bergerak itu, maka penggugat harus mengembalikan sejumlah pengganti perdamaian itu kepada tergugat seluruhnya atau sebagian, dan penggugat itu berhak mengajukan gugatan itu kepada orang yang menuntut dan yang punya hak tersebut.

7. Jika seluruh atau sebagian dari pengganti kerugian itu diambil 
oleh penggugat, maka penggugat

berhak mengajukan gugatan atas penggantian perdamaian.

8. Jika pihak penggugat berkeinginan memperoleh kembali hartanya, dan menyetujui suatu perdamaian untuk mendapat sebagian dari padanya, serta membebaskan tergugat dari sisa perkara yang diajukan, maka penggugat dianggap telah menerima pembayaran sebagian dari tuntutannya dan membebaskan sisanya.

9. Jika seseorang melaksanakan suatu perdamaian dengan orang lain tentang sebagian dari tuntutannya kepada orang itu, maka orang yang melaksanakan perdamaian itu dianggap telah menerima pembayaran sebagian dari tuntutannya dan telah melepaskan haknya terhadap sisanya.

10. Jika seseorang melaksanakan suatu perdamaian di mana suatu utang yang segera harus dibayar, diubah menjadi utang yang dapat dibayarkan kembali di kemudian hari, maka ia dianggap telah melepaskan haknya untuk pembayaran segera.

11. Jika seseorang melaksanakan suatu perdamaian tentang suatu utang yang harus dibayar kembali dengan sesuatu barang, bisa dibayar dengan barang lain yang sama nilainya, maka orang itu dianggap telah menunaikan kewajibannya.

12. Apabila suatu proses perdamaian telah diselesaikan, maka tidak satu pun dari kedua pihak berhak mempermasalahkannya lagi.

13. Dengan disetujuinya perdamaian itu, maka penggugat berhak atas penggantian perdamaian yang tercantum dalam transaksi perdamaian itu.

14. Jika salah satu pihak yang melakukan transaksi perdamaian meninggal dunia, maka ahli warisnya tidak berhak membatalkan perdamaian itu.

15. Jika perdamaian itu dibuat dalam bentuk pertukaran barang, maka 
kedua pihak boleh menghapuskan dan menggugurkan perdamaian itu atas kehendak mereka sendiri.

16. Jika suatu transaksi perdamaian yang dibuat berisi suatu pembayaran yang dilakukan agar dapat menghindari pengucapan sumpah, maka penggugat dianggap telah dapat memaksa tergugat untuk bersumpah.

17. Jika objek pengganti dalam perdamaian rusak sebagian atau seluruhnya sebelum diserahkan kepada penggugat, dan pengganti kerugian itu berupa barang tertentu, maka ini dianggap sama halnya dengan suatu barang yang diambil seseorang yang berhak atas barang itu.

18. Jika suatu perdamaian dibuat dengan cara pengakuan, maka penggugat berhak menuntut seluruh atau sebagian barang yang dituntutnya dari perdamaian tersebut dari tergugat.

19. Jika pengganti kerugian dalam perdamaian berupa suatu piutang atau berupa barang yang tidak tertentu, maka perdamaian itu tidak akan terpengaruh oleh hal tersebut, dan penggugat berhak untuk menerima sejumlah yang sama dengan kerugiannya, dari tergugat. ${ }^{14}$

H. Akad Shulh dalam Sengketa Muamalah di Pengadilan

Walaupun para ulama mengupayakan agar terjadinya perdamaian (shulb) di luar pengadilan, namun akad shulb pun bisa dilakukan di pengadilan dengan menggunakan pihak ketiga (dalam hal ini Hakim) untuk melakukan mediasi, apabila upaya damai tersebut tidak berhasil, baru diselesaikan melalui proses persidangan (litigasi) seperti sesuai dengan ketentuan hukum acara perdata yang berlaku di Pengadilan Agama.

Sudah menjadi asas dalam hukum acara perdata bawah

14 Dewan Syariah Nasional - Majelis Ulama Indonesia, Op. Cit., h. 145-148. 
Jurnal Syariah: Jurnal Ilmu Hukum dan Pemikiran Vol 17, Nomor 2 Desember 2017
Akad Shulh dalam Sengketa ..127-142

Ma'rifah Yuliani pengadilan (hakim) wajib mendamaikan pihak berperkara. ${ }^{15}$ Asas ini mengharuskan pengadilan (hakim) agar dalam menangani suatu perkara perdata yang diajukan kepadanya terlebih dahulu berupaya mendamaikan kedua belah pihak berperkara. Upaya mendamaikan kedua belah pihak berperkara di persidangan adalah sesuatu yang imperative (wajib dilakukan). Kelalaian hakim mengupayakan perdamaian bagi kedua belah pihak berperkara akan mengakibatkan batalnya pemeriksaan perkara tersebut demi hukum. ${ }^{16}$

Terkait dengan upaya damai yang harus dilakukan hakim dalam rangka menyelesaikan perkaraperkara di bidang ekonomi syariah umumnya dan bidang lembaga keuangan syariah khususnya, di lingkungan peradilan agama, paling tidak ada dua ketentuan yang harus diperhatikan, yaitu: ketentuan Pasal

15 A. Mukti Arto, Praktik Perkara Perdata pada Pengadilan Agama, (Yogyakarta: Pustaka Pelajar, 1996), h. 12.

16 M. Yahya Harahap, Hukum Acara Perdata, (Jakarta: Sinar Grafika, 2005), h. 239 .
154 R.Bg/130 HIR dan Peraturan Mahkamah Agung (PERMA) No. 01 Tahun 2008 tentang Prosedur Mediasi di Pengadilan.

Upaya damai yang harus
dilakukan hakim atas dasar
ketentuan Pasal $154 \mathrm{R} . \mathrm{Bg} / 130 \mathrm{HIR}$
dipahami lebih bersifat anjuran,
bahkan dikatakan bercorak formalitas dan regulatif serta sukarela (voluntary), tidak bersifat memaksa. Namun setelah diterbitkannya PERMA Mo. 01 Tahun 2008, Upaya damai yang harus dilakukan hakim di persidangan tidak lagi hanya sebatas anjuran atau imbauan yang bersifat formalitas saja, melainkan sudah bersifat memaksa. ${ }^{17}$

Dari keterangan mengenai adanya PERMA No. 01 Tahun 2008 ini menandakan bahwa shulh juga bisa terjadi di luar maupun di dalam pengadilan, dan dari penelitian ini terdapat sebuah permasalah yang

17 Cik Basir, Penyelesaian Sengketa Perbankan Syariah di Pengadilan Agama dan Mabkamah Syar'iyah, (Jakarta: Kencana, 2009), h. 126-128. 
menarik untuk dikaji lebih dalam, yakni "Apakah dalam PERMA No. 01 Tahun 2008 tentang proses mediasi sebelum adanya litigasi sudah sesuai ketentuannya dengan konsep Akad Shulh."

I. Akad Shulh dalam Sengketa Muamalah

Penggunaan akad shulh dalam tiga bentuk persengketaan muamalah adalah sebagai berikut:

1. Pertama, shulb dapat digunakan untuk menyelesaikan sengketa dimana gugatan penggugat diakui oleh tergugat. Misalnya seseorang menggugat bahwa tetangganya berutang sejumlah uang kepadanya dan tetangga tersebut mengakuinya. Kerelaan membayar hutang dari tetangga tersebut termasuk shulh.

2. Kedua, shulb dapat digunakan untuk menyelesaikan sengketa di mana gugatan penggugat tidak diakui oleh tergugat. Menurut Jumhur ulama, perdamaian seperti ini boleh dilakukan dan hukumnya sah. Pandangan berbeda dari sebagian ulama Syafi'I dan Ibn Abi Laila, yang berpendapat bahwa perdamaian dalam sengketa yang diingkari tergugat hukumnya tidak boleh, karena setiap orang bisa mengklaim hak orang lain. Menurut mereka, hal ini akan bermuara pada menghalalkan yang haram atau mengharamkan yang halal.

3. Ketiga, sbulb dapat digunakan dalam menyelesaikan sengketa di mana gugatan penggugat tidak ditanggapi oleh tergugat. Tergugat tidak mengakui dan tidak pula mengingkari gugatan itu. Dalam kasus seperti ini terjadi perbedaan pendapat ulama. Jumhur ulama berpendapat bahwa perdamaian dalam kasus seperti ini diperbolehkan, karena ayat dan hadis yang membolehkan shulb berlaku secara umum. Namun, pandangan ulama Syafi'i dan Ibn Abi Laila yang berpendapat 
Jurnal Syariah: Jurnal Ilmu Hukum dan Pemikiran Vol 17, Nomor 2 Desember 2017

bahwa perdamaian seperti ini tetap tidak diperbolehkan, karena sikap diam dan tidak ada tanggapan dari tergugat menunjukkan sikap pengingkaran. Penerapan shulh seperti ini termasuk dalam kategori menghalalkan yang haram dan mengharamkan yang halal. ${ }^{18}$

J. Akad Shulh dalam Sengketa Non Litigasi (Di Luar Pengadilan)/Alternative Dispute Resolution (ADR).

Pranata

penyelesaian sengketa alternatif dikenalkan oleh UU No. 30 tahun 1999, sebagaimana diatur dalam Pasal 6 terdiri dari:

a. Penyelesaian yang dapat dilaksanakan sendiri oleh para pihak dan bentuk negosiasi.

b. Penyelesaian sengketa yang diselenggarakan melalui (dengan bantuan) pihak ketiga yang netral di luar para

${ }^{18}$ Syahrizal Abbas, Op. Cit., h. 212.
Akad Shulh dalam Sengketa ..127-142 Ma'rifah Yuliani

pihak yaitu dalam bentuk mediasi.

Kemudian jika cara diatas menemui jalan buntu maka penyelesaian diserahkan ke arbitrase. Dengan demikian, secara umum cara penyelesaian sengketa di luar pengadilan (ADR) dikenal dalam bentuk berbagai penyelesaian. Bentuk-bentuk penyelesaian tersebut yakni: Negosiasi; Konsultasi; Mediasi; Konsiliasi; dan Arbitrase. Tujuan adanya negosiasi, konsultasi, mediasi, konsiliasi dan arbitrase adalah terjalinnya jalan tengah (perdamaian/shulb) di antara kedua belah pihak yang bersengketa.

\section{Penutup}

A. Simpulan

Pengertian Shulh dalam Kompilasi Hukum Ekonomi Syariah (KHES) adalah suatu jenis akad untuk mengakhiri jenis perselisihan atau kesepakatan untuk menyelesaikan pertikaian secara damai dan saling memaafkan. Shulh yang merupakan perdamaian 
Jurnal Syariah: Jurnal Ilmu Hukum dan Pemikiran

dimasukkan ke dalam Buku II tentang Akad dalam KHES.

Sbulh bisa terjadi di luar pengadilan maupun di dalam pengadilan (Menurut PERMA No. 01 Tahun 2008). Proses adanya mediasi di pengadilan awalnya hanya berupa anjuran dari ketentuan Pasal 154 R.Bg/130 HIR. Namun setelah lahirnya PERMA No. 01 Tahun 2008 maka proses mediasi atas penyelesaian sengketa secara damai menjadi bersifat memaksa.

B. Saran

Akad shulb sudah diaplikasikan ke dalam sengketa di pengadilan, hal ini terlihat dari PERMA No. 01 Tahun 2008 berupa adanya mediasi atas penyelesaian sengketa secara damai yang bersifat memaksa. Penggunaan akad shulh di luar proses pengadilan terlihat dari penggunaan negosiasi, mediasi yang bertujuan untuk mendamaikan kedua belah pihak yang berselisih, apabila terjadi arbitrase maka tujuan yang ingin dicapai pun adalah
Akad Shulh dalam Sengketa ..127-142

Ma'rifah Yuliani

terciptanya keridhaan di antara kedua belah pihak yang bersengketa.

\section{Daftar Pustaka}

Abbas, Syahrizal, Mediasi dalam Hukum Syariah, Hukum Adat dan Hukum Nasional, Jakarta: Kencana, 2011.

Arifin, Busthanul, Pelembagaan Hukum Islam di Indonesia: Akar Sejarah, Hambatan, dan Prospeknya, Jakarta: Gema Insani Press, 1996.

Arto, A. Mukti, Praktik Perkara Perdata pada Pengadilan Agama, Yogyakarta: Pustaka Pelajar, 1996.

Basir, Cik, Penyelesaian Sengketa Perbankan Syariah di Pengadilan Agama dan Mahkamah Syariyah, Jakarta: Kencana, 2009.

Dahlan, Abdul Azis, ed, Ensiklopedi Hukum Islam, Jakarta: Ichtiar Baru van Hoeve, 1996.

Dewan Syariah Nasional - Majelis Ulama Indonesia, Kompilasi Hukum Ekonomi Syariah. 
Jurnal Syariah: Jurnal Ilmu Hukum dan Pemikiran Vol 17, Nomor 2 Desember 2017
Akad Shulh dalam Sengketa ..127-142

Ma'rifah Yuliani

Harahap, M. Yahya, Hukum Acara

Perdata, Jakarta: Sinar Grafika, 2005.

Mujahiddin, Ahmad, Kewenangan dan Prosedur Penyelesaian Sengketa

Ekonomi Syariah di Indonesia,

Bogor: Ghalia Indonesia, 2010.

Mujieb, M. Abdul, dkk, Kamus Istilah

Fiqih, Jakarta: Pustaka Firdaus, 1995.

Sabiq, Sayyid, Fikih Sunnah: juz 13, diterjemahkan oleh Kamaluddin A. Marzuki, Bandung: Al-Ma’arif, 1997.

Zaidah, Yusna, Penyelesaian Sengketa Melalui Peradilan dan Arbitrase Syariah di Indonesia, Yogyakarta: Aswaja Pressindo, 2015.

Az-Zuhaily, Wahbah, Fiqib Islami Wa Adillatubu 6, diterjemahkan oleh Abdul Hayyie al-Kattani, dkk, Jakarta: Gema Insani, 2011. 